\title{
AEPIDEMIOLOGIA E A PESQUISA NA SAÚDE E NA ENFERMAGEM
}

Ana Lúcia Cardoso Kirchhof ${ }^{1}$

Alguns autores costumam afirmar que o objeto de trabalho da Enfermagem é o cuidado ${ }^{(1)}$, para outros, o cuidado é o objeto epistemológico ${ }^{(2)}$, no sentido de que é para melhor cuidar que desvendamos teorias e desenvolvemos tecnologias. O cuidado seria nossa força motriz, propulsora do conhecimento da enfermagem e nossa ação política. Considero que o sujeito - quer receba a denominação de paciente, doente, usuário, enfermo, cliente ou mesmo membro de um grupo - seja o nosso objeto de trabalho e, tal qual variam as denominações, variam também as percepções e as teorizações sobre esse objeto e sua forma de cuidá-lo. Canguilhem ${ }^{(3)}$ já nos alertava para as diferentes qualidades entre o objeto de conhecimento e o objeto observado, reduzindo uma possível ingenuidade na compreensão do alcance e aplicabilidade do conhecimento produzido.

Temos, portanto, muitos desafios a trilhar, e um bom exemplo deles são os oito desafios estabelecidos para serem atingidos até 2015, compartilhados por 191 Estados-Membros das Nações Unidas ${ }^{(4)}$. São eles: erradicar a extrema pobreza e a fome; atingir o ensino básico universal; promover a igualdade entre os sexos e a autonomia das mulheres; reduzir a mortalidade infantil; melhorar a saúde materna; combater o HIV/Aids, a malária e outras doenças; garantir a sustentabilidade ambiental; e estabelecer uma parceria mundial com o desenvolvimento. Certamente, esses desafios nos incitam a questionar a nossa capacidade de produção e incorporação dos conhecimentos produzidos para o cuidado em saúde.

Mais do que nunca se comprova que os determinantes para se ter saúde não estão somente no setor saúde, mas vão muito além da criação/produção de conhecimentos, tecnologias e serviços que visam tratar doenças. Acesso a emprego, nutrição, transporte, água limpa e saneamento, bem como a proteção de direitos são também todos de grande importância como determinantes da saúde ${ }^{(5)}$. Saúde, portanto, está diretamente vinculada a produção e a materialização do conhecimento para a qualidade de vida. Mas, para tanto, há que se levar em conta os padrões de desenvolvimento e adoecimento da sociedade/grupos populacionais, indivíduos.

A Epidemiologia, uma disciplina que vem se estruturando ao longo da caminhada histórica e teórica da formulação do processo saúde-doença e seus paradigmas ${ }^{(6)}$ é, sem dúvida, um importante instrumento para produzir conhecimento, tanto em pesquisas quantitativas, quanto em pesquisas qualitativas. Mesmo que não nos demos conta ela subsidia grande parte das práticas de saúde quando contribui para o conhecimento da ocorrência de doenças de um modo geral, para o estudo de relações causais; na distribuição, na qualidade e na adequação dos serviços de saúde; na supervisão, avaliação e vigilância do processo saúde-doença e, ainda, em estudos experimentais, com finalidade de testes terapêuticos ${ }^{(7)}$.

A Enfermagem, ao se utilizar da epidemiologia, pode desenvolver estudos de promoção, prevenção e avaliação do cuidado, se dêem eles em áreas temáticas como o planejamento de serviços; a construção de programas e estratégias; a investigação e controle de processos mórbidos ou não, mas que tenham vinculação com a morbidade ou mortalidade; o estudo de modelos assistenciais e gerenciais para qualificar melhor o cuidado. É sempre bom relembrar que a evolução do arcabouço conceitual/operacional de uma disciplina está vinculada às relações que ela consegue estabelecer com a apropriação e a transformação do conhecimento. A socialização tem sua importância tanto para possibilitar sua aplicabilidade quanto para sofrer as devidas críticas a suas proposições. Assim, as condições de saúde, como expressão concreta de vida, coloca aos pesquisadores e profissionais de saúde questões que irão exigir modelos construídos a partir de paradigmas que sejam capazes de absorver várias áreas do conhecimento.

Considero, portanto, que a Epidemiologia proporciona uma potente ferramenta para os profissionais da Enfermagem usarem em suas pesquisas e na aplicação das mesmas na sua prática profissional.

${ }^{1}$ Enfermeira. Doutora. Professora Aposentada do Departamento de Enfermagem da Universidade Federal de Santa Catarina-UFSC. Pesquisadora Visitante da Universidade Federal do Paraná-UFPR. Grupo de Estudos e Pesquisas em Administração e Gerência do Cuidado em Enfermagem e Saúde-GEPADES-UFSC. Núcleo de Estudos sobre Trabalhos, Cidadania, Saúde e Enfermagem-UFSC. Grupo de Pesquisa Trabalho, Saúde, Educação e Enfermagem-Universidade Federal de Santa Maria-UFSM.E-mail: kirchhof@terra.com.br

Cogitare Enferm 2009 Abr/Jun; 14(2):212-6 
1. Castellanos B, Rodrigues AM, Almeida MCP, Rosa MTL, Mendes SASA. Os desafios da enfermagem para os anos 90 . In: Anais do $41^{\circ}$ Congresso Brasileiro de Enfermagem, 1989, set 2-7; Florianópolis (SC): ABEn 1989. p.147-69.

2. Leopardi MT, Gelbecke FL, Ramos FRS. Cuidado: objeto de trabalho ou objeto epistemológico da enfermagem? Texto Contexto Enferm. 2001 Jan/Abr; 10(1):32-49.

3. Canguilhem G. O Normal e o patológico. $2^{\mathrm{a}}$ ed. Rio de Janeiro: Forense-Universitária; 1982.

4. Presidência da República (BR). Objetivos de desenvolvimento do milênio: relatório de acompanhamento. Coordenação: Instituto de Pesquisa Econômica Aplicada e Secretaria de Planejamento e Investimentos Estratégicos. Brasília:Ipea, SPI, Set 2007.152p.

5. Ministério da Saúde (BR). Secretaria de Ciência, Tecnologia e Insumos Estratégicos. Departamento de Ciência e Tecnologia. Por que pesquisa em saúde? Brasília: Ministério da Saúde, 2007. 20p. Série B: Textos Básicos de Saúde/ Série Pesquisa para Saúde: Textos para a Tomada de Decisão.

6. Silva GR. Avaliação e perspectivas da epidemiologia no Brasil. Conferência de encerramento do $1^{\circ}$ Congresso Brasileiro de Epidemiologia, Anais, Rio de Janeiro: ABRASCO, 1990, p. 108-39.

7. Morris JN. Uses of epidemiology. London: Churchill Livingstone; 1975 


\section{EPIDEMIOLOGY AND RESEARCH IN HEALTH AND IN NURSING}

\section{Ana Lúcia Cardoso Kirchhof ${ }^{1}$}

Some authors use to affirm that caring is the Nursing work object ${ }^{(1)}$; to others, caring is the epistemological object ${ }^{(2)}$, in a way that we unveil theories and develop technologies to enhance care. Caring could be our driving force, which fosters Nursing knowledge and our political action. I consider that the subject patient, user, ill person, client or member of a group - is our work object and, in the same way his denomination may vary, the perceptions and theorizations on this object and the way we care for it may also vary. Canguilhem ${ }^{(3)}$ already remarked us to the different predicates between the object of knowledge and the observed object, reducing a presumable naivety in the comprehension of the significance and applicability if the produced knowledge.

Therefore, there are many challenges to be defeated, and one good example is the eight established challenges to be pursuit until 2015, shared by 191 United Nation's State-Members ${ }^{(4)}$. These are: to eradicate the extreme poverty and hunger; to attain the universal basic education; to promote equality among sexes and women authonomy; to reduce children's mortality; to enhance maternal health; to fight HIV/ Aids, malaria and other diseases; to ensure environmental sustainability; and to establish a world partnership towards development. Certainly, these challenges encourage us to question our capability to produce and incorporate the produced knowledge to the health care.

More than ever, it can be proved that the determinants to be healthy are not only in the health sector, but they can be found further than the knowledge, technology and services production which focus on the disease treatment. Job access, nutrition, transportation, clean water and sanitation, as well as rights protection are also very important health determinants ${ }^{(5)}$. Thus, health is straightly bounded to the production and the knowledge materialization into quality of life. But, we should consider the individual's, populational groups' and societies' patterns of development and illness.

Epidemiology, a discipline that is being structured during the historical and theoretical journey of the development of the health-disease process and its paradigms $^{(6)}$ is, beyound question, an important tool to produce knowledge, both in quantitative and qualitative researches. Even though we don't realize this, it supports a great amount of health practices in contributing to the recognition of the diseases' occurrence in a general way; to the study of causal relations; to the distribution, in terms of quality and adequacy of health services; to the supervision, evaluation and vigilance of the healthdisease process and, still, in experimental studies, regarding therapeutic tests ${ }^{(7)}$.

Nursing, when working with Epidemiology, can develop caring promotion, prevention and evaluation studies, which could be developed in theme areas such as health services planning; strategies and program development; investigation and control of morbid process or not, but that could be linked with morbidity or mortality; and studies of models of care and management to enhance caring. It's always good to remember that the evolution of a discipline's conceptual/operational framework is bounded to the relationships that it could establish with the knowledge's appropriation and processing. Its socialization is important both to enable it applicability and to be criticized on their propositions. Therefore, health conditions, as concrete expression of life, question the health personnel and researchers demanding that their answers would be founded by paradigms that could assimilate many knowledge fields. Thus, I consider that Epidemiology enables a powerful tool for Nursing professionals to use in their researches and its application in their professional practice.

\section{REFERÊNCIAS}

1. Castellanos B, Rodrigues AM, Almeida MCP, Rosa MTL, Mendes SASA. Os desafios da enfermagem para os anos 90. In: Anais do $41^{\circ}$ Congresso Brasileiro de Enfermagem, 1989, set 2-7; Florianópolis (SC): ABEn 1989. p.147-69.

2. Leopardi MT, Gelbecke FL, Ramos FRS. Cuidado: objeto de trabalho ou objeto epistemológico da enfermagem? Texto Contexto Enferm. 2001 Jan/Abr; 10(1):32-49.

3. Canguilhem G. O Normal e o patológico. $2^{\mathrm{a}}$ ed. Rio de Janeiro: Forense-Universitária; 1982.

4. Presidência da República (BR). Objetivos de desenvolvimento do milênio: relatório de acompanhamento. Coordenação: Instituto de Pesquisa Econômica Aplicada e Secretaria de Planejamento e Investimentos Estratégicos. Brasília:Ipea, SPI, Set 2007.152p.

5. Ministério da Saúde (BR). Secretaria de Ciência, 
Tecnologia e Insumos Estratégicos. Departamento de Ciência e Tecnologia. Por que pesquisa em saúde? Brasília: Ministério da Saúde, 2007. 20p. Série B: Textos Básicos de Saúde/ Série Pesquisa para Saúde: Textos para a Tomada de Decisão.

6. Silva GR. Avaliação e perspectivas da epidemiologia no Brasil. Conferência de encerramento do $1^{\circ}$ Congresso Brasileiro de Epidemiologia, Anais, Rio de Janeiro: ABRASCO, 1990, p. 108-39.

7. Morris JN. Uses of epidemiology. London: Churchill Livingstone; 1975

\section{LAEPIDEMIOLOGÍAY LA INVESTIGACIÓN EN LA SALUD Y EN LA ENFERMERÍA}

Ana Lúcia Cardoso Kirchhof ${ }^{1}$

Algunos autores acostumbran afirmar que el objeto del trabajo de Enfermería es el cuidado ${ }^{(1)}$, para otros, el cuidado es el objeto epistemológico ${ }^{(2)}$, en el sentido de que es para mejor cuidar que desvendamos teorías y desarrollamos tecnologías. El cuidado sería nuestra fuerza motriz, propulsora del conocimiento de la enfermería y nuestra acción política. Considero que el sujeto - reciba la denominación de paciente, enfermo, usuario, cliente o incluso miembro de un grupo - sea nuestro objeto de trabajo y, tal cual varían las denominaciones, varían también las percepciones y las teorizaciones sobre ese objeto y su forma de cuidarlo. Canguilhem ${ }^{(3)}$ ya nos alertaba para las diferentes cualidades entre el objeto de conocimiento y el objeto observado, reduciendo una posible ingenuidad en la comprensión del alcance y aplicabilidad del conocimiento producido.

Tenemos, por lo tanto, muchos desafíos a trillar, y un buen ejemplo de ellos son los ocho desafíos establecidos para ser alcanzados hasta 2015, compartidos por 191 Estados-Miembros de las Naciones Unidas ${ }^{(4)}$. Son ellos: erradicar la extrema pobreza y el hambre; alcanzar la enseñanza básica universal; promover la igualdad entre los sexos y la autonomía de las mujeres; reducir la mortalidad infantil; mejorar la salud materna; combatir el HIV/SIDA, la malaria y otras enfermedades; garantizar la sustentabilidad ambiental; y establecer una sociedad mundial con el desarrollo. Ciertamente, estos desafíos nos incitan a cuestionar nuestra capacidad de producción e incorporación de los conocimientos producidos para el cuidado en salud.

Más que nunca se comprueba que los determinantes para tener salud no están solamente en el sector salud, pero van más allá de la creación/ producción de conocimientos, tecnologías y servicios que visan tratar enfermedades. Acceso a empleo, nutrición, transporte, agua limpia y saneamiento, bien como la protección de derechos son también, todos, de gran importancia como determinantes de la salud ${ }^{(5)}$. Salud, por lo tanto, está directamente vinculada a producción y materialización del conocimiento para la calidad de vida. Pero, para tanto, deben ser llevados en cuenta los padrones de desarrollo y padecimiento de la sociedad/grupos poblacionales, individuos.

La Epidemiología, una disciplina que viene estructurando-se a lo largo de la caminata histórica y teórica de la formulación del proceso saludenfermedad y sus paradigmas ${ }^{(6)}$ es, sin duda, un importante instrumento para producir conocimiento, tanto en investigaciones cuantitativas, como en investigaciones cualitativas. Aunque no nos demos cuenta, ella subsidia gran parte de las prácticas de salud cuando contribuye para el conocimiento de la ocurrencia de enfermedades de un modo general, para el estudio de relaciones casuales; en la distribución, en la calidad y en la adecuación de los servicios de salud; en la supervisión, evaluación y vigilancia del proceso salud-enfermedad y, todavía, en estudios experimentales, con finalidad de testes terapéuticos( ${ }^{(7)}$.

La Enfermería, al hacer uso de la epidemiología, puede desarrollar estudios de promoción, prevención y evaluación del cuidado, siendo ellos en áreas temáticas como la planificación de servicios; la construcción de programas y estrategias; la investigación y control de procesos mórbidos o no, pero que tengan vinculación con la morbidez o mortalidad; el estudio de modelos asistenciales y gerenciales para calificar mejor el cuidado. Es siempre bueno recordar que la evolución del esbozo conceptual/operacional de una disciplina está vinculada a las relaciones que ella consigue establecer con la apropiación y la transformación del conocimiento. La socialización es importante tanto para posibilitar su aplicabilidad como para sufrir las debidas críticas a sus proposiciones. Así, las condiciones de salud, como expresión concreta de vida, coloca a los investigadores y profesionales de salud cuestiones que irán exigir modelos construidos a partir de paradigmas que sean capaces de absorber varias áreas del conocimiento.

Considero, por lo tanto, que la Epidemiología 
proporciona una potente herramienta para los profesionales de la Enfermería para utilización en sus investigaciones y en la aplicación de las mismas en su práctica profesional.

\section{REFERÊNCIAS}

1. Castellanos B, Rodrigues AM, Almeida MCP, Rosa MTL, Mendes SASA. Os desafios da enfermagem para os anos 90. In: Anais do $41^{\circ}$ Congresso Brasileiro de Enfermagem, 1989, set 2-7; Florianópolis (SC): ABEn 1989. p.147-69.

2. Leopardi MT, Gelbecke FL, Ramos FRS. Cuidado: objeto de trabalho ou objeto epistemológico da enfermagem? Texto Contexto Enferm. 2001 Jan/Abr; 10(1):32-49.

3. Canguilhem G. O Normal e o patológico. $2^{\mathrm{a}}$ ed. Rio de Janeiro: Forense-Universitária; 1982.

4. Presidência da República (BR). Objetivos de desenvolvimento do milênio: relatório de acompanhamento. Coordenação: Instituto de Pesquisa Econômica Aplicada e Secretaria de Planejamento e Investimentos Estratégicos. Brasília:Ipea, SPI, Set 2007.152p.

5. Ministério da Saúde (BR). Secretaria de Ciência, Tecnologia e Insumos Estratégicos. Departamento de Ciência e Tecnologia. Por que pesquisa em saúde? Brasília: Ministério da Saúde, 2007. 20p. Série B: Textos Básicos de Saúde/ Série Pesquisa para Saúde: Textos para a Tomada de Decisão.

6. Silva GR. Avaliação e perspectivas da epidemiologia no Brasil. Conferência de encerramento do $1^{\circ}$ Congresso Brasileiro de Epidemiologia, Anais, Rio de Janeiro: ABRASCO, 1990, p. 108-39.

7. Morris JN. Uses of epidemiology. London: Churchill Livingstone; 1975 